\title{
PENGARUH POLA MAKAN SEHAT ISLAM TERHADAP PENCEGAHAN OBESITAS DI MASYARAKAT KP. GEBANG RT/RW 004/002 TAHUN 2020
}

\author{
Anggilia Kusumawardani $^{1}$, Yuliana ${ }^{2}$, Ayu Pratiwi ${ }^{2}$ \\ ${ }^{1}$ Mahasiswa Keperawatan STIKes Yatsi Tangerang \\ 2 Dosen S1 Keperawatan STIKes Yatsi Tangerang \\ Jl. Aria Santika Margasari, No. 40A Bugel Karawaci Kota \\ Tangerang
}

\begin{abstract}
ABSTRAK
Pendahuluan: Kehidupan yang semakin canggih dan modern didukung dengan berkembangnya ilmu dan teknologi serta adanya makanan fast food, maka akan berpengaruh terhadap kesehatan masyarakat. Tujuan Penelitian: untuk mengetahui pengaruh pola makan sehat islam terhadap pencegahan obesitas di masyarakat Kp. Gebang RT/RW 004/002. Metode Penelitian: penelitian menggunakan desain korelasional dengan pendekatan cross sectional. Populasi dalam penelitian ini sebanyak 135 responden dan sampel penelitian menggunakan random sampling sebanyak 101 responden. Teknik pengumpulan data yang digunakan adalah pendekatan dan observasi. Metode analisa data yang digunakan yaitu Chi Square. Instrumen penelitian menggunakan kuisioner dan observasi indeks massa tubuh (IMT). Hasil penelitian: pada variabel pola makan sehat islam dan pencegahan obesitas didapatkan hasil uji Chi Square dengan nilai $p$ value $0,782>0,05$. Kesimpulan: berdasarkan penelitian disimpulkan bahwa tidak ada pengaruh pola makan sehat islam terhadap pencegahan obesitas.
\end{abstract}

Kata Kunci: Pola Makan Sehat Islam, Pencegahan Obesitas.

\begin{abstract}
Introduction: An increasingly sophisticated and modern life, supported by the development of science and technology and the existence of fast food, will have an effect on public health. Purpose of the study: to find out the effect of a healthy Islamic diet on obesity prevention in the community Kp. Gebang RT/RW 004/002. Methods: This study used a correlational design with a cross sectional approach. The population in this study were 135 respondents and the study sample used random sampling of 101 respondents. The data collection techniques used were approaches and observations. The data analysis method used is Chi Square. The research instrument used a questionnaire and observation of body mass index (BMI). The results: on the variable Islamic healthy diet and obesity prevention, the Chi Square test results were obtained with a $p$ value of $0.782>0.05$. Conclusion: based on the study, it is concluded that there is no correlation between the effect of a healthy Islamic diet on obesity prevention.
\end{abstract}

Keywords: Islamic Healthy Diet, Prevention of Obesity. 


\section{PENDAHULUAN}

Kesehatan adalah keadaan sejahtera meliputi fisik, mental, sosial dan tidak hanya terbebas dari penyakit atau kelemahan (WHO, 2015). Kesehatan adalah keadaan yang diinginkan setiap orang, tetapi masih banyak orang yang tidak memperdulikan kesehatanya terutama dari pola makan yang sehat. Pola makan sehat rasulullah saw. Berpusat untuk memenuhi pengendalian gizi pada makanan. Rasulullah saw juga memilih makanan secara selektif dari segi kehalalan serta kebaikannya. Ukuran kehalalan makanan juga berhubungan dengan cara mendapatkannya secara halal (legal) yang berkaitan dengan akhiat dan kebaikan (thayyib) yang berkaitan dengan duniawi berupa makanan yang bergizi (Setyaningrum, 2018).

Yang dijelaskan dalam firman Allah SWT. (QS. 'Abasa/80:24)

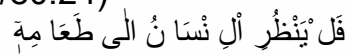

Artinya : "Maka hendaknya manusia itu memperhatikan makanannya"

Makan adalah kebutuhan utama manusia, Makanan juga mempengaruhi metabolisme dalam tubuh. Metabolisme dapat memproses sebuah zat, yang kemudian zat tersebut dirubah secara kimia maupun secara mekanik yang kemudian dirubah menjadi nutrisi ,dan dari nutrisi berubah menjadi energi. Begitupun Rasulullah menyampaikan bahwa berlebihan itu membuat iman menjadi lemah seolah-olah hidup dipusatkan untuk memenuhi nafsu makan saja, Makan secara berlebihan dapat memicu terjadinya penyakit yang membuat tubuh tidak mampu mencerna segala makanan yang masuk ke dalam tubuh dan bisa mengakibatkan penumpukan lemak dalam tubuh sehingga tubuh menjadi tidak ideal atau biasanya disebut obesitas (Tahlili, 2019). Dalam firman Allah SWT. (QS. AlA'raf/7:31)

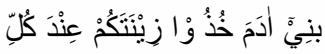

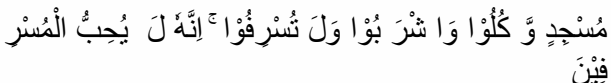

Artinya : "Wahai anak cucu adam, pakailah pakaianmu yang bagus setiap (memasuki) masjid, makan dan minumlah tetapi jangan berlebihan, Sungguh Allah tidak menyukai orang yang berlebih-lebihan".

Kehidupan yang semakin canggih dan modern serta didukung dengan berkembangnya ilmu dan teknologi, dengan diadakan makanan junk food atau fast food di masyarakat, makanan tersebut dapat menimbulkan dampak positif dan negatif bagi kesehatan. Dampak positif teknologi mampu meningkatkan kuantitas dan kualitas pangan, juga meningkatkan diversivikasi, praktis dan lebih ekonomis. Dampak negatif kemajuan teknologi akan mengakibatkan berubahnya pola makan dengan tinggi kalori , tinggi lemak dan kolesterol yang berdampak risiko meningkatkan obesitas. Makanan cepat saji juga dikenal masyarakat dengan istilah junk food. Terlalu sering mengkonsumsi makanan cepat saji dapat menimbulkan gangguan kesehatan seperti obesitas atau kegemukan, diabetes, hipertensi, penyakit jantung koroner, stroke, kanker, dan lain sebagainya. Namun, kebiasaan makan dengan mengonsumsi makanan cepat saji atau junk food berlebih akan berdampak buruk bagi kesehatan, baik pada anak, remaja, maupun dewasa. Kebanyakan manusia yang hidup saat ini mencari sesuatu yang mudah dan instan karena keterbatasan waktu dan kesibukan (Evan et al., 2017).

Seorang dikatakan overweight bila berat badannya $10 \%$ sampai dengan $20 \%$ berat badan normal, sedangkan seseorang disebut obesitas apabila kelebihan berat badan mencapai lebih $20 \%$ dari berat normal. Obesitas saat ini menjadi permasalahan dunia bahkan Organisasi Kesehatan Dunia (WHO) mendeklarasikan sebagai epidemic global (WHO, 2016). Obesitas merupakan keadaan patologis yang terdapat penimbunan lemak berlebih dari yang dibutuhkan fungsi tubuh normal dan merupakan konsekuensi dari asupan kalori (energi) yang melebihi jumlah kalori yang dilepaskan atau dibakar melalui proses metabolisme didalam tubuh yang disebabkan oleh faktor genetic, faktor lingkungan, faktor psikososial, faktor kesehatan, aktifitas fisik, faktor usia, faktor jenis kelamin. 
(Miko \& Pratiwi, 2017; Kyle, 2015; Siyoto, 2014).

Prevalensi obesitas di seluruh dunia meningkat lebih dari dua kali lipat pada tahun 2014 dengan lebih dari 1.9 miliar orang dewasa mulai usia 18 tahun, mengalami kelebihan berat badan dan dari jumlah tersebut lebih dari 600 juta mengalami obesitas (Sugiatmi \& Handayani, 2018).

Prevalensi di Indonesia dari Tahun 2007 - 2018: Pada Tahun 2007 Berat Badan Berlebih 8,6 \%, Tahun 2013 sebesar 11,5 \% dan Tahun 2018 mencapai $13,6 \quad \%$ sedangkan Obesitas dari Tahun 2007 sebesar 10,8\%, Tahun 2013 sebesar $14,8 \%$ dan Tahun 2018 meningkat menjadi 21,8 \% (Kemenkes RI, 2013).

Pada tahun 2015, jumlah kunjungan puskesmas dan jaringannya (usia >15 th) yang dilaporkan tercatat 18.734.668 orang, dari jumlah tersebut yang dilakukan pengukuran obesitas dilaporan sebanyak 3.383.501.orang terdiri dari laki-laki 1.681 .737 orang dan perempuan 1.701.764 orang dari hasil pengukuran obesitas diperoleh persentase obesitas sebesar 19,35 persen dengan rincian pada laki-laki sebesar 17,79 persen dan perempuan sebesar 20,52 persen. Terdapat dua Kabupaten atau Kota yang tidak melaporkan hasil pengukuran obesitas yaitu Kabupaten Serang, dan Kota Tangerang. Kabupaten atau Kota dengan persentase obesitas tertinggi adalah Kabupaten Pandeglang yaitu 33,35 persen, Kabupaten atau kota dengan persentase obesitas terrendah adalah Kota Cilegon yaitu 3,43 persen (Riskesdas, 2018).

Pada tanggal 20 Desember 2019 peneliti melakukan studi pendahuluan di Kp. Gebang RT/RW 004/002 didapatkan populasi masyarakat berjumlah 135 orang. Peneliti melakukan wawancara kepada 5 masyarakat Kp. Gebang $\mathrm{RT} / \mathrm{RW}$ 004/002. Hasil wawancara disimpulkan bahwa masyarakat masih sering mengkonsumsi makanan tinggi lemak seperti jeroan, mengkonsumsi makanan yang digoreng, dan tidak pernah berolahraga minimal seminggu $3 x$. Berdasarkan uraian di atas peneliti tertarik untuk mengadakan penelitian dengan judul Pengaruh Pola Makan
Sehat dalam Islam Terhadap Pencegahan Obesitas di Masyarakat Kp. Gebang RT/RW 004/002.

\section{METODE PENELITIAN}

Desain penelitian menggunakan desain korelasional dengan pendekatan Cross Sectional. Waktu Penelitian 06 s/d 08 Juli 2020. Populasi dalam penelitian ini sebanyak 135 responden .dan Sampel Penelitian sebanyak 101 responden diambil menggunakan Random Sampling dengan Kriteria Inklusi dan Ekslusi. Teknik pengumpulan data yang digunakan adalah pendekatan dan observasi. Metode analisa data yang digunakan yaitu Chi Square dengan menggunakan SPSS Tipe 22. Instrument penelitian menggunakan kuisioner dan observasi indeks massa tubuh (IMT).

\section{HASIL PENELITIAN}

Tabel 1. Karakteristik Umur Responden

\begin{tabular}{ccc}
\hline Umur & $(\boldsymbol{f})$ & $(\%)$ \\
\hline $\begin{array}{c}\mathbf{2 9 - 3 5} \\
\text { Tahun }\end{array}$ & 27 & $26,7 \%$ \\
$\begin{array}{c}\mathbf{1 6 - 2 1} \\
\text { Tahun }\end{array}$ & 10 & $9,9 \%$ \\
\hline Total & 101 & $100,0 \%$ \\
\hline
\end{tabular}

Berdasarkan Tabel 1 didapatkan karakteristik umur responden tertinggi yaitu umur 29-35 tahun sebanyak 27 responden $(26,7 \%)$.

Tabel 2. Karakteristik Jenis Kelamin Responden

\begin{tabular}{ccc}
\hline $\begin{array}{c}\text { Jenis } \\
\text { Kelamin }\end{array}$ & $(\boldsymbol{f})$ & $(\%)$ \\
\hline Laki-laki & 40 & $39,6 \%$ \\
Perempuan & 61 & $60,4 \%$ \\
\hline Total & 101 & $100,0 \%$ \\
\hline
\end{tabular}

Berdasarkan Tabel 2 didapatkan karakteristik jenis kelamin responden tertinggi yaitu jenis kelamin perempuan sebanyak 61 responden $(60,4 \%)$. 
Tabel 3. Kategori Indeks Massa Tubuh Responden

\begin{tabular}{ccc}
\hline Variabel & $(\boldsymbol{f})$ & $(\%)$ \\
\hline Normal & 59 & $58,4 \%$ \\
Kurus & 3 & $3 \%$ \\
\hline Total & 101 & $100,0 \%$ \\
\hline
\end{tabular}

Berdasarkan Tabel 3 diketahui kategori indeks massa tubuh responden tertinggi yang memiliki kategori normal sebanyak 59 responden $(58,4 \%)$.

Tabel 4. Pola Makan Sehat Islam

\begin{tabular}{ccc}
\hline Variable & $(\boldsymbol{f})$ & $(\%)$ \\
\hline Tinggi & 90 & $89,1 \%$ \\
Rendah & 11 & $10,9 \%$ \\
\hline Total & 101 & $100,0 \%$ \\
\hline
\end{tabular}

Berdasarkan Tabel 4 didapatkan distribusi frekuensi responden dengan pengetahuan pola makan sehat islam yang tinggi sebanyak 90 responden $(89,1 \%)$.

Tabel 5. Pencegahan Obesitas

\begin{tabular}{ccc}
\hline Variable & $(\boldsymbol{f})$ & $(\%)$ \\
\hline Baik & 68 & $67,3 \%$ \\
$\begin{array}{c}\text { Kurang } \\
\text { Baik }\end{array}$ & 33 & $32,7 \%$ \\
\cline { 1 - 1 } Total & 101 & $100,0 \%$ \\
\hline
\end{tabular}

Berdasarkan Tabel 5 diketahui distribusi frekuensi responden dengan pencegahan obesitas yang baik sebanyak 68 responden $(67,3 \%)$.
Tabel 6. Chi Square

\begin{tabular}{|c|c|c|c|c|c|c|c|}
\hline \multicolumn{8}{|c|}{ Pencegahan Obesitas } \\
\hline \multirow{2}{*}{$\begin{array}{c}\text { Pola } \\
\text { Makan } \\
\text { Sehat } \\
\text { Islam }\end{array}$} & \multicolumn{2}{|c|}{$\begin{array}{c}\text { Kurang } \\
\text { Baik }\end{array}$} & Baik & Tot: & & & \multirow[t]{2}{*}{$P$ value } \\
\hline & $\mathrm{N}$ & $\%$ & $\mathrm{~N}$ & $\%$ & $\mathrm{~N}$ & $\%$ & \\
\hline \multirow[t]{2}{*}{ Rendah } & 77 & 63,6 & 4 & $36,4 \%$ & 11 & 100 & \multirow{4}{*}{0,782} \\
\hline & & $\%$ & & & & $\%$ & \\
\hline \multirow[t]{2}{*}{ Tinggi } & 61 & 67,8 & 29 & $32,2 \%$ & 90 & 100 & \\
\hline & & $\%$ & & & & $\%$ & \\
\hline \multirow[t]{2}{*}{ Total } & 33 & $32,7 \%$ & 68 & $67,3 \%$ & 101 & 100 & \\
\hline & & & & & & $\%$ & \\
\hline
\end{tabular}

Berdasarkan uji chi square tabel 6 diketahui $p$-value $0,782>0,05$ yang artinya Ho diterima dan Ha ditolak maka dapat disimpulkan bahwa tidak ada pengaruh pola makan sehat islam terhadap pencegahan obesitas.

\section{PEMBAHASAN}

1. Gambaran Karakteristik Demografi Masyarakat Kp. Gebang RT/RW 004/002

Berdasarkan karakteristik responden usia didapatkan karakteristik umur responden tertinggi yaitu umur 29-35 tahun sebanyak 27 responden $(26,7 \%)$. Berdasarkan karakteristik jenis kelamin responden tertinggi didapatkan yaitu jenis kelamin perempuan sebanyak 61 responden $(60,4 \%)$. Dapat disimpulkan bahwa berdasarkan jenis kelamin dan usia masyarakat Kp. Gebang RT/RW 004/002 dapat disimpulkan bahwa yang mengalami obesitas pada perempuan sebanyak 8 responden $(7,9 \%)$ dengan usia 27-44 tahun. Sedangkan hasil penelitian (Mawaddah, 2017) menunjukkan bahwa usia terbanyak adalah berusia 30- 49 tahun yaitu 59 orang $(65,6 \%)$ maka dapat disimpulkan bahwa semakin usia bertambah dapat memicu terjadinya obesitas jika masyarakat tidak mau merubah kebiasaan buruk dengan tidak menjaga pola makan sesuai aturan islam, tetap menjalani kebiasaan buruk seperti sering mengkonsumsi makanan cepat saji, 
makan tinggi lemak dan makan secara berlebihan. Karakteristik yang didapatkan berdasarkan usia dan jenis kelamin sejalan dengan hasil penelitian (Nadimin, 2015) sebagian besar berjenis kelamin perempuan $(68,4 \%)$, yang berumur 55-60 tahun (25\%) dan 19-24 tahun $(21,1 \%)$. Hal ini disebabkan karena metabolisme wanita lebih lambat dari pria, basal metabolic rate (tingkat metabolisme pada kondisi isirahat) wanita $10 \%$ lebih rendah dibandingkan pria, maka wanita cenderung lebih banyak mengubah makanan menjadi lemak sedangkan pria mengubah makanan menjadi otot atau cadangan energy yang siap pakai, karena otot membakar lebih banyak lemak daripada sel-sel lain. Kegemukan merupakan kelebihan lemak tubuh karena tidak ada keseimbangan antara kalori yang dikonsumsi dan energy yang dikeluarkan. Semakin usia bertambah maka metabolic rate semakin melambat.

Berdasarkan Tabel 3 diketahui kategori indeks massa tubuh responden tertinggi yang memiliki kategori normal sebanyak 59 responden $(58,4 \%)$.

Penelitian sejalan dengan hasil penelitian menurut (Yulianawati, 2016) mengalami obesitas ringan sebanyak 19 mahasiswa $(42,2 \%)$ dan menurut (Ekawati, 2014) dikatakan obesitas ringan dengan IMT 23-24,9, obesitas sedang dengan IMT 25-29,9, dan obesitas berat dengan IMT $\geq 30$. Selain memperhatikan kehalalan dan keharaman dari makanan yang akan mahasiswa konsumsi, penting bagi mahasiswa untuk berpuasa SeninKamis. Seperti yang dikutip dari Kompas (2012), banyak manfaat yang bisa didapatkan dari puasa Senin-Kamis seperti keseimbangan anabolisme dan katabolisme, tidak akan mengakibatkan pengasaman dalam darah, penurunan glukosa dan berat badan, bermanfaat bagi jantung, memperbaiki dan merestorasi fungsi dan kinerja sel dan lain sebagainya.

\section{Gambaran Pengetahuan Pola Makan Sehat Islam}

Berdasarkan tabel 4 didapatkan distribusi frekuensi responden dengan pengetahuan pola makan sehat islam yang tinggi sebanyak 90 responden $(89,1 \%)$. Hasil penelitian sejalan dengan
(Miko \& Pratiwi, 2017) sampel yang memiliki kebiasaan makan baik memiliki persentase sebesar $(56,2 \%)$ dan yang memiliki kebiasaan makan kurang baik sebesar $(43,8 \%)$ didapatkan pola makan yang berlebihan dan tinggi energi pada remaja cenderung berakibat terhadap meningkatnya komposisi berat badan yang berdampak terhadap resiko obesitas.

Dalam pandangan sains, makan secara berlebihan hingga memenuhi volume maksimal lambung memang tidak baik, karena jika lambung yang berfungsi untuk mencerna karbohidrat tidak bisa bekerja secara maksimal, makanan yang dimakan menjadi sia-sia. Jadi, makan yang baik memang secukupnya saja, namun dengan nutrisi yang lengkap. (Rahayu, 2017).

\section{Gambaran Pencegahan Obesitas}

Berdasarkan Tabel 5 diketahui distribusi frekuensi responden dengan pencegahan obesitas yang baik sebanyak 68 responden $(67,3 \%)$. Hasil penelitian ilmiah (Rahayu, 2017) telah membuktikan bahwa pola makan atau diet ala rasul tersebut dapat memperpanjang umur seseorang dan mengatasi kegemukan atau obesitas yang merupakan menyebab dari berbagai penyakit. Istilah diet yang memiliki makna yang sama yaitu dalam hal proses pemilihan makanan dan pengaturan makanan yang dikonsumsi oleh tubuh.

Berikut pengertian diet adalah pilihan makanan yang lazim dimakan seseorang atau suatu populasi penduduk. Menurut dr. Kunkun, kegemukan timbul karena seseorang kelebihan energi. Jumlah energi yang masuk, yang berasal dari makanan, melebihi energi yang digunakan oleh tubuh. Penderita dapat mengulangi kelebihan tersebut dengan diet. Ada empat macam diet, yaitu diet serat untuk menghambat proses penyerapan nutrisi penghasil energi, diet rendah kalori tidak seimbang, puasa, dan diet seimbang rendah kalori.

\section{Hubungan Pola Makan Sehat Islam terhadap Pencegahan Obesitas \\ Berdasarkan Uji Chi Square}


diketahui $p$-value $0,782>0,05$ yang artinya Ho diterima dan Ha ditolak maka dapat disimpulkan bahwa tidak ada pengaruh pola makan sehat islam terhadap pencegahan obesitas masyarakat Kp. Gebang. Pada penelitian ini tidak ada pengaruh dikarenakan masyarakat Kp. Gebang memiliki tingkat pengetahuan pola makan sehat islam yang tinggi serta perilaku dalam pencegahan obesitas untuk diri sendiri dan keluarga baik, tetapi ada beberapa masyarakat yang masih mengabaikan dan tidak memperhatikan kesehatannya dalam pencegahan obesitas dengan mengkonsumsi makanan secara berlebihan dan masih mengkonsumsi makanan tinggi lemak dan makanan cepat saji.

Sebagian besar dari hasil indeks massa tubuh yang didapatkan masyarakat yang memiliki berat badan ideal. Penelitian ini sejalan dengan hasil penelitian dari (Miko \& Pratiwi, 2017) bahwa 52 mahasiswa dengan berat badan ideal normal pada umumnya memiliki aktivitas fisik yang baik yaitu sebanyak 32 mahasiswa $(84,2 \%)$ dan dari 10 mahasiswa dengan berat badan ideal tidak normal pada umumnya juga memiliki aktivitas fisik yang baik yaitu 6 mahasiswa $(15,8 \%)$ di Program Studi Jurusan Gizi Politeknik Kesehatan Kemenkes Aceh. Hasil uji statistik diperoleh nilai probabilitas yaitu sebesar $1,000(p>0,05)$, hal ini menunjukkan tidak ada hubungan yang signifikan antara berat badan ideal dengan aktifitas fisik Mahasiswa Program Studi Jurusan Gizi Politeknik Kesehatan Kemenkes Aceh Tahun 2015.

Berdasarkan penelitian (Evan, 2017) dari analisis data dengan mengunakan uji kolerasi Spearman Rank dengan mengunakan bantuan program SPSS, didapatkan $p$ value $=0,002<\alpha(0,05)$ atau data signifikan yang artinya ada "ada hubungan antara pola makan dengan kejadian obesitas pada mahasiswa di Universitas Tribhuwana Tunggadewi Malang". Hasil pengumpulan data didapatkan bahwa sebagian besar mahasiswa memiliki pola makan tinggi hal ini didapatkan pada 24 $(77,4 \%)$ responden dan sebagian besar mahasiswa memiliki obesitas I hal ini didapatkan pada 29 (93,5\%) responden. Berdasarkan data khusus didapatkan bahwa sebagian besar responden berumur 23 tahun sebanyak 7 (22,6\%) responden dan sebagian besar responden memiliki jenis kelamin perempuan sebanyak $27 \quad(87,1 \%)$ responden mahasiswa di Universitas Tribhuwana Tunggadewi Malang.

Begitu pula hasil penelitian (Nyoman Arya Shridewi Abhigamika, 2019) untuk variabel kuantitas makanan dan intensitas makan yang memiliki nilai Chi-square hitung lebih kecil dibandingkan nilai Chi-square tabel yakni 4,272 dan 3,885 yang berarti kedua variabel tersebut memberikan pengaruh terhadap obesitas remaja. Nilai koefisien korelasi (r)kuantitas makanan dan intensitas makan $>0,05$ yakni sama-sama $\quad 0,068$ sehingga hubungan kedua variabel tersebut searah dengan kejadian obesitas remaja. Kuantitas makanan dan intensitas makan masing-masing hanya mampu menjelaskan terjadinya obesitas remaja sebesar $0,46 \%$ dilihat dari nilai determination coefficient (R2). Sedangkan tingkat keyakinan kuantitas makanan sebesar $1,4 \%$ dan intensitas makan sebesar $1,27 \%$ terhadap hubungannya dengan obesitas remaja jika dilihat dari nilai contingency coefficient (C). Berdasarkan hasil tersebut, nilai R2 dan $\mathrm{C}$ dari ketiga variabel sangat rendah. Hal ini disebabkan oleh pola makan yang hanya merupakan salah satu dari berbagai faktor risiko lainnya yang dapat menimbulkan obesitas sedangkan faktor-faktor tersebut seperti aktivitas fisik, genetik, status sosial-ekonomi yang turut mempengaruhi terjadinya obesitas tidak diteliti pada studi ini. Penelitian serupa yang dilakukan oleh Mujur (2011) pada remaja SMA 4 Semarang mendapatkan hasil adanya hubungan yang bermakna antara pola makan dengan kelebihan berat badan. Hasil uji statistic penelitian tersebut memiliki tingkat signifikansi $p=0,005$ menggunakan uji pearson 
chi-square dengan prevalensi rasio $3,00 \quad(95 \% \quad$ confidence interval 1,303-6,905).

Berdasarkan hasil penelitian (Roshita Yulianawati, 2016) dapat diketahui bahwa dari hasil uji statistik menggunakan korelasi $\operatorname{lambda}(\lambda)$ dengan bantuan program komputer dihasilkan nilai probabilitas (p) sebesar 0,030 . Nilai probabilitas tersebut kemudian dibandingkan dengan nilai alpha $(\alpha)$ yaitu 0,05 . Apabila nilai $p<\alpha$ maka Ho ditolak yang berarti ada hubungan antara pola makan dengan tingkat obesitas. Dari penelitian tersebut dapat diketahui bahwa p $(0,030)<\alpha$ $(0,05)$ sehingga Ho ditolak yang berarti ada hubungan antara pola makan dengan tingkat obesitas. Dari hasil uji statistik tersebut dapat dilihat nilai korelasi lambda $(\lambda)$ sebesar 0,429 yang berarti keterikatan hubungan dalam kategori sedang. Keterikatan dalam penelitian ini termasuk dalam kategori sedang karena tingkat obesitas dapat dipengaruhi berbagai faktor lainnya, seperti faktor aktifitas fisik yaitu seseorang dengan aktivitas fisik yang kurang, faktor lingkungan yaitu perilaku atau pola gaya hidup seseorang apa yang dimakan dan beberapa kali makan dan faktor psikososial yaitu apa yang ada dalam pikiran seseorang dapat mempengaruhi kebiasaan makannya (Proverawati, 2010).

\section{KESIMPULAN}

Dari hasil penelitian tentang pengaruh pola makan sehat islam terhadap obesitas di masyarakat Kp. Gebang $\mathrm{Rt} / \mathrm{Rw}$ 004/002 dapat disimpulkan :

1. Pengaruh pola makan sehat islam terhadap pencegahan obesitas disimpulkan bahwa tidak ada pengaruh pola makan sehat islam terhadap pencegahan obesitas

\section{DAFTAR PUSTAKA}

1. Adnyana \& Sudhana, (2019). Hubungan Antara Pola Makan Dengan Obesitas Remaja Pada Siswa-Siswi Sekolah Menengah Atas (SMA) Di Denpasar)
2. Depkes. (2010). Kriteria Indeks Massa Tubuh (IMT).

3. Dinas Kesehatan Republik Indonesia. (2013). Riset Kesehatan Dasar.

4. Dwipayana, I. M. P. (2018). Perbedaan Prevalensi Obesitas dan Berat Badan Lebih pada Siswa Sekolah Menengah Atas (SMA) Negeri Antara Daerah Urban dan Rural di Kabupaten Gianyar. EJurnal Medika Udayana, 7(2), 72-76.

5. Evan, E., Wiyono, J., \& Candrawati, E. (2017). Hubungan Antara Pola Makan Dengan Kejadian Obesitas Pada Mahasiswa Di Universitas Tribhuwana Tunggadewi Malang. Nursing News: Jurnal Ilmiah Mahasiswa Keperawatan, 2(3), 708-717.https://publikasi.unitri.ac.id/i nde x.php/fikes/article/view/707

6. Mawaddah, N. (2017). Gambaran Pola Makan Dan Kejadian Obesitas Di Masyarakat Gayo.

7. Miko, A., \& Pratiwi, M. (2017). Hubungan Pola Makan dan Aktivitas Fisik dengan Kejadian Obesitas Mahasiswa Politeknik Kesehatan Kemenkes Aceh. AcTion: Aceh Nutrition Journal, 2(1), 1. https://doi.org/10.30867/action.v2i1. 29

8. Notoatmodjo, S. (2018). Metodologi Penelitian Kesehatan (3rd ed.). Rineka Cipta.

9. Pramesti, G. (2014). Kupas Tuntas Data Penelitian dengan SPSS 22. Elex Media Komputindo.

10. Rahayu, M. (2017). Pola Makan Menurut Hadis Nabi SAW.

11. Riskesdas, K. (2018). Hasil Utama Riset Kesehatan Dasar (RISKESDAS). Journal of Physics A: Mathematical and Theoretical, 44(8), 1-200. https://doi.org/10.1088/17518113/44/8/085201

12. Setyaningrum, L. (2018). Tips Sehat Rasul: Panduan Sederhana Pola Makan dan Hidup Sehat Ala Rasulullah SAW(1st ed.). Trans Idea Publishing.

13. Sugiatmi, S., \& Handayani, D. R. (2018). Faktor Dominan Obesitas pada Siswa Sekolah Menengah Atas di Tangerang Selatan Indonesia. Jurnal Kedokteran Dan Kesehatan, 
E - ISSN : $2722-127 \mathrm{X}$

$P$ - ISSN : $2338-4700$

14(1),https://doi.org/10.24853/jkk.14 $.1 .1-10$

14. Tahlili, S. K. (2019). Pola Makan Menurut Hadis Nabi SAW. 7, 295313.

15. Yulianawati, R. (2016). Hubungan Pola Makan Dengan Tingkat Obesitas Pada Mahasiswa IImu Keperawatan Di Universitas 'Aisyiyah Yogyakarta. 